\title{
The Distribution and Accretion of Some Heavy Metals in Makkah Wells
}

\author{
Nezar H. M. Khdary ${ }^{1}$, Ahmed E. H. Gassim² \\ ${ }^{1}$ King Abdulaziz City for Science and Technology, Riyadh, KSA \\ ${ }^{2}$ Makkah Toxicology Center, Research Unit, Makkah, KSA \\ Email: nkhdary@kacst.edu.sa, draassim@hotmail.com
}

Received 10 June 2014; revised 8 July 2014; accepted 2 August 2014

Copyright (C) 2014 by authors and Scientific Research Publishing Inc.

This work is licensed under the Creative Commons Attribution International License (CC BY). http://creativecommons.org/licenses/by/4.0/

\section{(c) (i) Open Access}

\section{Abstract}

The aim of this study is to determine the types of heavy metals frequently present in Makkah wells and the possible environmental causes of their distribution and accumulation. Makkah lies in a mountain range dominated by different types of rocks from the Precambrian and Lower Paleozoic eras, as well as subordinate sedimentary rocks and basaltic lava flow from the Tertiary and Quaternary periods. Natural contaminants in Makkah wells water can be attributed to the unique location. Many epidemiological studies have identified associations between the ingestion of wells water contaminated with heavy metals and increased risk of some illnesses. This study presents exclusive information on the levels and distribution of 9 heavy metals-arsenic, barium, cadmium, chromium, cobalt, copper, lead, mercury, and selenium-in the wells water in various rural and urban areas of Makkah city. These naturally occurring elements are considered significant markers of water purity. More than 160 wells were involved in this three-year investigation. Water samples were collected during different seasons in order to assess any changes in the distribution and concentration of these heavy metals throughout the year. The collected water samples were filtered and digested before analysis using inductively coupled plasma mass spectrometry (ICP/MS). We found the following sequence of concentrations of heavy metals in the studied wells: $\mathrm{Ba}>\mathrm{Se}>\mathrm{Cr}>\mathrm{As}>\mathrm{Co}>\mathrm{Cu}>\mathrm{Hg}>\mathrm{Pb}>\mathrm{Cd}$. Arsenic, barium, chromium, and selenium were the most abundant contaminants in the wells studied. The concentrations of the other heavy metals ranged from non-detectable to $3 \mu \mathrm{g} / \mathrm{L}$. Although low, these values are also reported in comparisons with the local and international strict values and standards which govern the maximum contaminant levels permitted for long-term daily consumption.

\section{Keywords}

Makkah Wells, Water Contamination, Heavy Metals, Rural and Urban Areas, ICP/MS 


\section{Introduction}

Water is essential for life on earth, and we can say that groundwater is generally presumed to be safe for human consumption and is used as a potential source of drinking water. The two main natural sources of water are surface water, such as lakes, rivers, and streams, and groundwater, such as borehole and well water [1] [2]. The four main water resources in the Kingdom of Saudi Arabia are surface water, groundwater, desalinated seawater, and treated wastewater. Of these, groundwater is considered the most important source of water in Saudi Arabia [3] [4]. Groundwater comes from shallow, renewable aquifers and deep, nonrenewable aquifers. Shallow aquifers contain a renewable water supply provided by rainfall and surface runoff. Shallow aquifers are affected by rainy seasons, which result in the dilution of heavy metals and other elements. Deep aquifers have a reservoir formed thousands of years ago when water was trapped in sedimentary rocks, such as limestone and sandstone [5]. Groundwater in the areas of Makkah selected for this study contains water mostly from nonrenewable sources, primarily runoff which seeped from metamorphic igneous rocks through the Wadi sediment to aquifers. Metal contamination of these aquifers can be predicted based on the type and composition of igneous and/or sedimentary rocks present. The selected wells in the Makkah area are in the southern Hijaz region, the west-central Arabian Shield. This area is dominated by different types of igneous, metamorphic, and sedimentary rocks from the Precambrian and Lower Paleozoic eras. In addition, there are subordinate sedimentary rocks and basaltic lava flow from the Tertiary and Quaternary periods. Mostly Precambrian intrusive rocks cover the area. Intermediate rocks, ranging in composition from diorite to tonalite predominate the Makkah batholiths in the Kamil suite. The dominant structural trend is northeast to north-northeast and reflects the three major phases of Precambrian deformation and Tertiary faulting [6].

The unique chemical properties of water, including polarity and the ability to form hydrogen bonds, govern its ability to dissolve, absorb, and suspend a wide variety of compounds. Water in nature is not pure because it acquires contaminants from its surroundings, many of which are derived from humans, animals, and biological activities. Among the wide variety of contaminants dissolved either completely or partially in water are heavy metals salts, in which heavy metals defined as any metallic element that has a relatively high density or, more precisely, a specific gravity greater than 5.0 [7]. Heavy metals salts may include acetate, chloride, sulfate, nitrate, oxides, and hydroxides of arsenic, cadmium, chromium, cobalt, lead, mercury and selenium. They are harmful if swallowed and are toxic or poisonous at low concentrations because of their ability to bio-accumulate at low exposure concentrations. A higher concentration of these heavy metals can occur over time in the living body than in the environment. Some of these heavy metals constantly accumulate in living bodies; they are ingested and stored faster than they are broken down (metabolized) or excreted. The high toxicity of heavy metals at low concentrations (especially lead, mercury, chromium, and metals with multivalent properties) makes bio-accumulation a particular concern [8]. Among groundwater contaminants, such heavy metals constitute the greatest environmental concern [9]. Heavy metals in well water usually attached to colloidal particles and liquefied phases. In water bodies, heavy metals result from natural sources (minerals in eroding sediment, leaching from ore deposits, and volcanism extruded products) and from anthropogenic sources (solid waste disposal, industrial and domestic effluents, and harbor channel dredging). The contamination levels of heavy metals are higher in urban road dusts than urban soils. Moreover, the main sources of the metals in urban soils, urban road dusts and agricultural soils are also different [10] [11]. Some heavy metals, such as cobalt, copper, iron, manganese, molybdenum, and zinc, are needed at low levels as catalysts for biological enzyme activity; however, excess levels can cause severe toxicity in the human body [12] [13]. In addition, heavy metals may cause serious health problems with various symptoms depending on the nature and quantity of metal ingested. Toxicity is commonly caused when the metal either forms complexes with proteins or reacts with groups such as carboxylic acid and amine. The products of these reactions lead to the inactivation of important enzymes in the body and/or breakdown of the cells, depending on the degree of exposure and type of metallic contaminant. Food and water intake are the main routes of entry for arsenic in the general population. Food is generally the most important source, but in some areas, drinking water is a significant source of inorganic arsenic. Contaminated soils surrounding areas such as mine tailings and rock-cutting industries are potential sources of arsenic exposure. The relationship between chronic arsenic exposure and health effects is unclear. There are some relatively strong evidences correlating arsenic exposure to hypertension and cardiovascular disease, they are suggestively links arsenic to diabetes and reproductive effects and weakly to cardiovascular disease, long-term neurological effects, and cancer at sites other than the lung, bladder, kidney, and skin (World Health Organization) [14]. Barium is not considered an essential 
element in human nutrition [15]. At high concentrations, barium causes vasoconstriction by direct stimulation of arterial muscles, peristalsis by violent stimulation of smooth muscles, and convulsions and paralysis by stimulation of the central nervous system [16]. Depending on the dose and solubility of the barium salt ingested, severe health problems may occur in a few hours or few days. Associations between the barium content of drinking water and mortality from cardiovascular disease have been observed in several ecological-epidemiological studies [17]. Exposure to cadmium above the maximum contaminant level (MCL) for relatively short periods of time causes nausea, vomiting, diarrhea, muscle cramps, salivation, sensory disturbances, liver injury, convulsions, shock, and renal failure. Lifetime exposure to cadmium above the MCL has the potential to cause kidney, liver, bone, and blood damage [18] [19]. Chromium enters the air, water, and soil as chromium (III) and chromium (VI) cations through natural processes and human activities. Contaminated well water may contain the dangerous chromium (VI), or hexavalent chromium. Several studies have shown that chromium (VI) compounds can increase the risk of lung cancer and that ingesting large amounts can cause upset stomach, ulcers, convulsions, kidney and liver damage, and even death [20] [21]. Cobalt is a transition metal, and a high concentration of it in water cause toxicity. At various doses, cobalt and nickel salts have been reported to induce convulsions [22], to cause DNA-strand breaks [23], and to be organ toxins [24]. Cobalt salts are thought to promote the oxidation of reduced glutathione [25], to lower the number of hepatic heme proteins such as cytochrome P450, and to interfere with heme metabolism by accelerating breakdown and inhibiting synthesis [26]. Although small amounts of copper is essential in the body, excess copper can be toxic and lead to hemolytic anemia, emotional problems, behavioral disorders, mood swings, depression, nephritis, schizophrenia, eczema, sickle cell anemia, and severe damage to the central nervous system [27] [28]. Lead is a cumulative poison and possible human carcinogen. Exposure to lead has been linked to the development of autoimmunity, causing joint diseases and ailments of the kidneys, circulatory system, and neurons. High concentrations of lead can cause irreversible brain damage [29]. Mercury toxicity results in mental disturbances and impairment of speech, hearing, vision, and movement [30], followed by nervous-system damage and ultimately resulting in learning disorders in children and the severe breakdown of the nervous system [31]. Similarly to lead, mercury may cause the development of autoimmunity and irreversible brain damage [32]. Individuals who drink well water containing selenium that exceeds the MCL for many years could experience hair or fingernail loss, numbness in the fingers or toes, and/or circulation problems [33] [34]. Considering the strong scientific correlation between heavy metal exposure and chronic illnesses, it is of paramount importance to study the presence and levels of heavy metals in natural water sources.

The accuracy of the results depends on the methods and techniques used, which prompts a brief mention of the methods used to achieve the objective of this study: the detection and assessment of heavy metals. Through many years of study, reliable methods to detect heavy metals in drinking water have been developed [35]-[39]. Sample preparations include relatively simple acidification than direct injection and a more complex one the submission to total oxidation/dissolution procedure achieved under elevated temperature and pressure in the appropriate acid(s). Aqueous solution is obtained through steps of samples preparation through the suitable instrumental techniques [40] [41]. Preconcentration procedures are needed for most of the advanced sensitive analysis methods to avoid the insufficient sensitivity of the direct submission of the samples to analysis [42][46]. Solid phase extraction based on the adsorption of the trace metal ions in a suitable adsorbent such as activated carbon, Amberlite XAD resins, Chromosorb resins, and modified silica are required in some cases. Definitely solid phase extraction is an excellent method for the preconcentration of drinking water for analysis, regardless of the water type and source [47]-[51]. As concern over concentrations of trace metal ions in drinking water has increased, organizations such as the WHO, U.S. EPA, and European Committee have recommended concentration limits. Detection of the concentration of trace metal ions requires greater sensitivity than achieved by flame atomic absorption spectrometry; therefore, inductively coupled plasma mass spectrometry (ICP/MS) was utilized for water sample analysis in this study. The conducted research covered both rural and urban areas of Makkah city. Most of the city and the central zone are supplied with desalinated water from the national network. Wells are the primary source of drinking and agricultural water for both the remote rural areas [52].

\section{Materials and Methods}

\subsection{Site Selection}

The groundwater in the areas of Makkah selected for this study contain well water mostly from sources consi- 
dered nonrenewable, frequently runoff water from metamorphic igneous rocks that seeps through the valley sediment to aquifers. Metal contamination in water from these aquifers can be predicted based on the type and composition of igneous and/or sedimentary rocks present. Figure 1 shows the a satellite image of the all wells location and the blue lines are the valleys, in the left up corner the small map represent the major sites that have been studied. Table 1 illustrates the coordinates of the major sites that have been studied and the name of each area with the symbol that have been selected for each area.

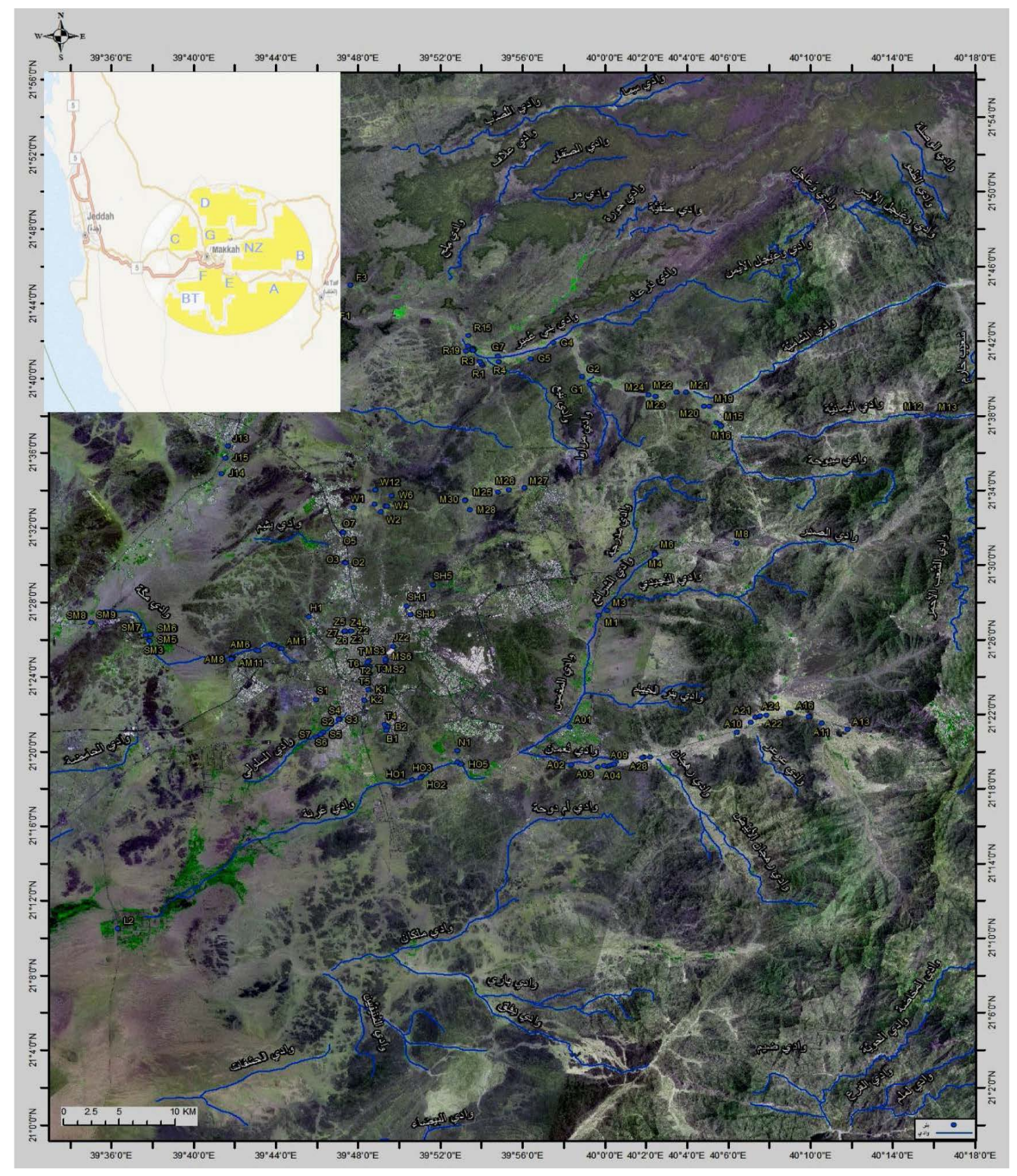

Figure 1. Satellite image of the sites studded and the valleys in blue lines. In the up left corner the area location and their symbols. 
Table 1. Selected locations and number of wells in the Makkah region.

\begin{tabular}{|c|c|c|c|c|}
\hline No. & Symbols & Areas & No. of wells & Location \\
\hline 1 & A & WadiNoman & 16 & $\mathrm{~N} 21^{\circ} 21.049^{\prime} \mathrm{E} 040^{\circ} 06.437^{\prime}$ \\
\hline 2 & B & Moghmas and Sharaie & 54 & $\begin{array}{l}\mathrm{N} 21^{\circ} 38.535^{\prime} \text { E040 } 04.839^{\prime} \\
\mathrm{N} 21^{\circ} 33.305^{\prime} \text { E039 } 48.813^{\prime}\end{array}$ \\
\hline 3 & $\mathrm{C}$ & Zaher and Shemeisi & 40 & $\begin{array}{l}\text { N21 }{ }^{\circ} 26.397^{\prime} \text { E039 } 48.208^{\prime} \\
\text { N21 } \\
\circ 27.367^{\prime} \\
\text { E039 } 50.562^{\prime}\end{array}$ \\
\hline 4 & $\mathrm{D}$ & Rayan and WadiHaneifah & 25 & $\begin{array}{l}\text { N21 }{ }^{\circ} 41.521^{\prime} \text { E039 }{ }^{\circ} 53.598^{\prime} \\
\text { N21 } 44.213^{\prime} \text { E039 } 46.800^{\prime}\end{array}$ \\
\hline 5 & E & Kakia and Sobahani & 8 & $\begin{array}{l}\text { N21 }{ }^{\circ} 22.786^{\prime} \text { E03948.328' } \\
\text { N21 } 21.050^{\prime} \text { E039 } 46.318^{\prime}\end{array}$ \\
\hline 6 & $\mathrm{~F}$ & Central zone & 8 & $\mathrm{~N} 21^{\circ} 25.663^{\prime} \mathrm{E} 039^{\circ} 49.740^{\prime}$ \\
\hline 7 & G & Tondobawi & 6 & $\mathrm{~N} 21^{\circ} 21.472^{\prime} \mathrm{E} 039^{\circ} 49.334^{\prime}$ \\
\hline 8 & BT & BathaaGhoriesh & 3 & $\mathrm{~N} 21^{\circ} 23.273^{\prime}$ E039 $53.470^{\prime}$ \\
\hline 9 & $\mathrm{NZ}$ & Aziziah & 8 & N21 $22.759^{\prime}$ E039 $53.441^{\prime}$ \\
\hline
\end{tabular}

\subsection{Chemicals}

All chemicals, reagents, and stock solutions of heavy metals $\left(100 \mathrm{mg} / \mathrm{L}\right.$ in $\left.4 \% \mathrm{HNO}_{3}\right)$ were ICP/MS- and ICP-grade, certified reference materials from Aldrich (U.S., nitric acid reagent/matrix, blank solution $5 \%$ in ASTM type water), Sigma-Aldrich (U.S., contract lab program AA/ICP hydrochloric acid reagent, matrix blank solution, $5 \%$ in ASTM type water), and Analytika (U.S., multi-element tune A, F and blank $2 \% \mathrm{HNO}_{3}$ ). Bottles used to transfer water samples to the laboratory were tested thoroughly and proven to be free of heavy metal contaminates and interferences. The preparation of standard solutions and calibration curves was carried out using stock solutions of $100 \mathrm{mg} / \mathrm{L}$ of ICP/MS-grade reagent. Serial dilutions were performed to obtain concentrations of 10, 20, 30, and $40 \mu \mathrm{g} / \mathrm{L}$ to cover the wide range of expected levels after quick screening. Nitric and hydrochloric acid (AA/ACP 5\%) were used to make the dilutions and blanks.

\subsection{Instruments}

A quadruple ICP-MS system (XSERIES 2 ICP-MS, Thermo Fisher Scientific, U.S.) was combined with PlasmaLab Thermo Fisher 2007 software configuration and quadruple parameters. They were set to an integration range of around peak $+/-$ (amu) 0.1 , minimum/maximum settle time ( $\mu$ second) of 1500/15,000 and safe resting mass (amu) of 4.5. A ASX-520 auto-sampler was also used. The selected heavy metals had linear calibration curves ranging from 10 to $40 \mu \mathrm{g} / \mathrm{L}$. The correlation coefficients for all metals ranged from 0.99961 to 0.973622 . A 1:1 mixture of $5 \%$ nitric acid and $5 \%$ hydrochloric acid in $100 \mathrm{ml}$ distilled/deionized water was used as a blank. The blank and the available deionized and distilled water used were analyzed and found to be free of any detectable heavy metals.

\subsection{Well-Water Sample Collection, Times, and Locations}

Water samples were collected from 9 areas, 6 in Makkah city (33 domestic wells) and 3 in rural locations surrounding Makkah (135 wells). Well-water samples were collected at different time intervals before and after the rainy seasons, although it rarely rains in Makkah. The frequency of sampling varied from once weekly to twice monthly during the three-year investigation. Unless stated otherwise, standard procedures were followed to collect, transport, pre-treat, and analyze the samples. Precautions were taken to avoid contamination during all steps. The EPA's Region II Low Stress Groundwater Sampling Protocol and Method 200.8 using the Thermo Scientific X-Series 2 ICP-MS were employed in this study. Non-disposable sampling equipment, including the pump, and support cable and electrical wires which contact the sample, were decontaminated thoroughly before each use. Containers for collecting samples were usually made of plastic or glass because these materials are relatively inert and easily cleaned. Glass containers were a good choice but were heavy and easily broken. Plastic containers had the advantage of lighter weight; however, they were not suitable for samples that were analyzed for organic compounds because of the potential for sample contamination from phthalate and other hydrocar- 
bons in the plastic or from the adsorption of the target analyte in the sample container. Glass containers were the best choice for organic constituents, but covers or caps were lined with Teflon. Sample containers were filled with care to prevent any portion of the collected sample from coming into contact with the sampler's gloves, thus causing contamination. Samples were not collected or stored in the presence of exhaust fumes. Once the sample was collected, it was stored and preserved to maintain the chemical and physical properties that it possessed at the time of collection.

\subsection{Water Sample Storage, Filtration, and Digestion}

The utmost care was taken to select the suitable sampling locations from the wells. Wide-mouth containers with Teflon-lined or polypropylene screw caps were used to collect and transfer water samples. The sampling containers were made of high-density polyethylene, and glass containers were used in cases where oil, grease, or creosote contamination was suspected. New containers underwent preconditioning before use. Containers were filled with water acidified with $5 \%$ hydrochloric acid and subjected to a 7-day leaching, followed by another 7-day leaching with water acidified with $5 \%$ nitric acid. Containers were rinsed with deionized water and allowed to air dry. Immediately before use, all bottles and containers were rinsed with a solution of deionized water and $10 \%$ reagent grade nitric acid or hydrochloric acid. The water samples from each well were collected in two 1-L bottles and immediately sent to the laboratory. The samples were kept in a refrigerator at $4^{\circ} \mathrm{C}$ for stabilization until analysis. The water samples were analyzed for chromium (VI) levels on the same day as collection. The rest of the metal analysis was carried out within a week of sampling. Filtration was performed to remove any suspended particles which could dissolve during the digestion step and produce interfering values. Digestion of the clear filtrate was performed by acidifying $50 \mathrm{ml}$ of the filtrate with $20 \mathrm{ml}$ of acid mixture (5\% nitric acid, $5 \%$ hydrochloric acid mixture: $1: 1$ ), followed by heating to $90^{\circ} \mathrm{C}-85^{\circ} \mathrm{C}$ for $2 \mathrm{~h}$ using an ultrasonic water bath. The reduced volume was made of up to $100 \mathrm{ml}$ with the acid mixture and then cooled at room temperature.

\section{Prepare Results and Discussion}

The results show that the vary concentrations of the 9 metals studied—arsenic, barium, cadmium, Chromium, cobalt, copper, lead, mercury, and selenium — were found in these wells as shown in Figure 2.

The most abundant metals were arsenic, barium, chromium, and selenium as illustrated in Figure 3. Independent of the metals' differing toxicities, $\mu \mathrm{g} / \mathrm{L}$ measurements of these heavy metals in the different wells found in the following trend: $\mathrm{Ba}>\mathrm{Se}>\mathrm{Cr}>\mathrm{As}>\mathrm{Cu}>\mathrm{Co}>\mathrm{Cd}>\mathrm{Hg}>\mathrm{Pb}$. Again, these metals' degree of toxicity to humans varies, and the observed pattern does not mean that either barium or chromium are more toxic than arsenic. However, the pattern shown in Figure 3 demonstrates that the presence of these metals in well water from different areas of Makkah can be useful for making predictions. For example, the high concentration of chromium strongly indicates that arsenic, selenium, and barium will also be present. The first metal in this sequence, barium is present as a trace element in both igneous and sedimentary rocks and thus in Makkah wells. However, the barium levels in drinking water are not as important as total intake. In the most sensitive epidemiological study conducted to date, there were no significant differences in blood pressure or the prevalence of cardiovascular disease between a population drinking water containing barium at a mean concentration of $7.3 \mathrm{mg} / \mathrm{L}$ in comparison with a population drinking water containing barium at a mean concentration of $0.1 \mathrm{mg} / \mathrm{L}$ [53] (Brenniman et al. 1985). Selenium is present in earth's crust and thus leaches into well water, often in association with sulfur-containing minerals. Levels of selenium in wells vary greatly by geographical area. Even in selenium-rich areas, the concentration in drinking water is likely to be small compared with that in locally produced food. Arsenic is found widely in Earth's crust in oxidation states of $-3,0,+3$, and +5 and often as sulfides, metal arsenide, and arsenate. In water, arsenic is present mostly as arsenate (+5), but in anaerobic conditions such as deep in wells, it is likely to be present as arsenite (+3). Normally, arsenic concentrations in natural water sources are less than $1-2 \mu \mathrm{g} / \mathrm{L}$. However, significantly elevated arsenic concentrations in Makkah wells can account for the sulfide mineral deposits and sedimentary deposits in the igneous volcanic rocks surrounding the city. Chromium is widely distributed through the earth's crust; the nature of the crust and the rocks dictate its level in groundwater in any particular area. Accordingly, somewhat high concentrations were detected in Makkah wells, but they did not exceed international and local standards (Europian Union EU 1998; Environment Protection Agency EPA 2011; Saudi Arabian Standards Organization SASO 1984; World Health Organization WHO 2010). 


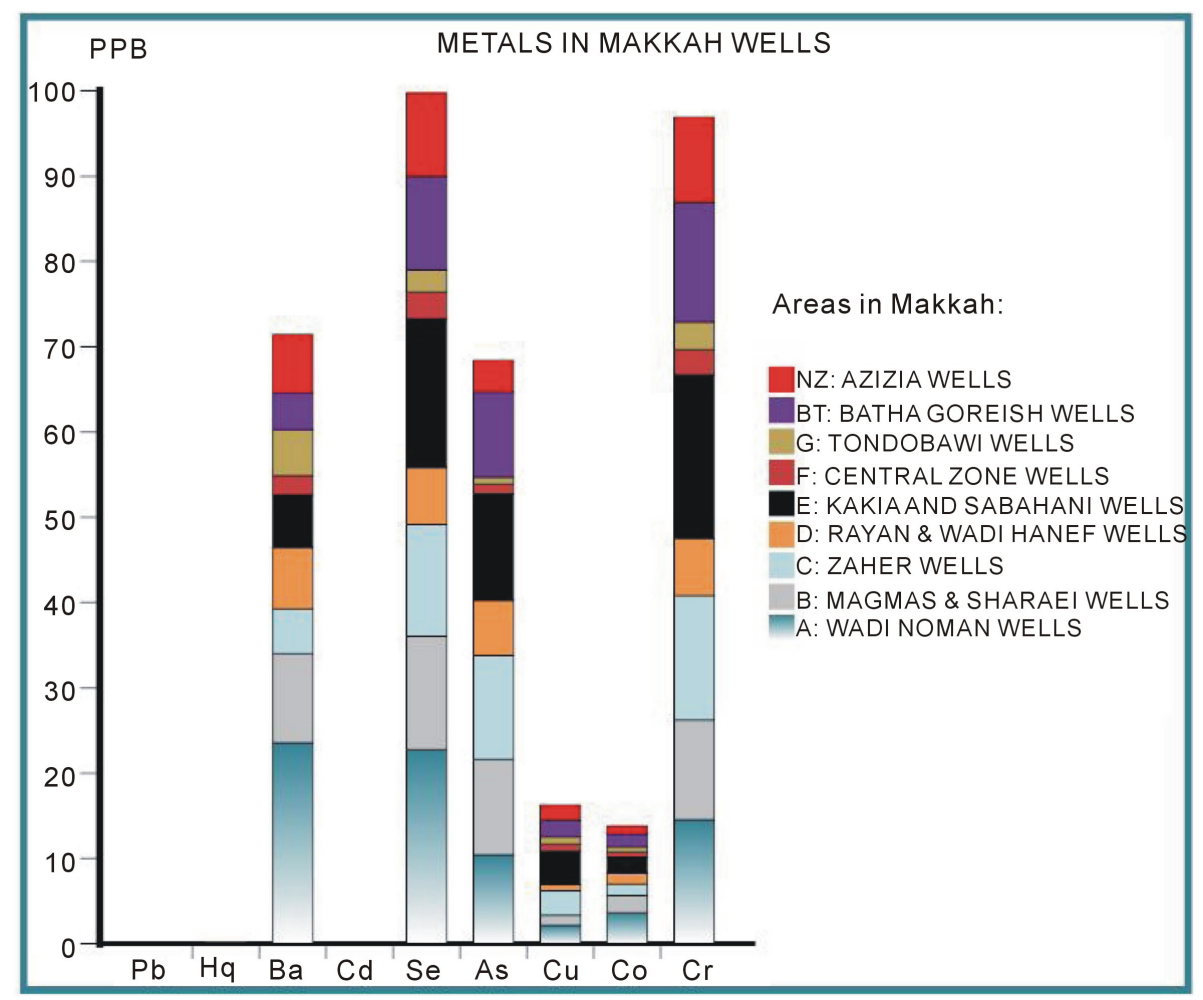

Figure 2. Pattern of the presence of the 9 studied heavy metals in Makkah wells.

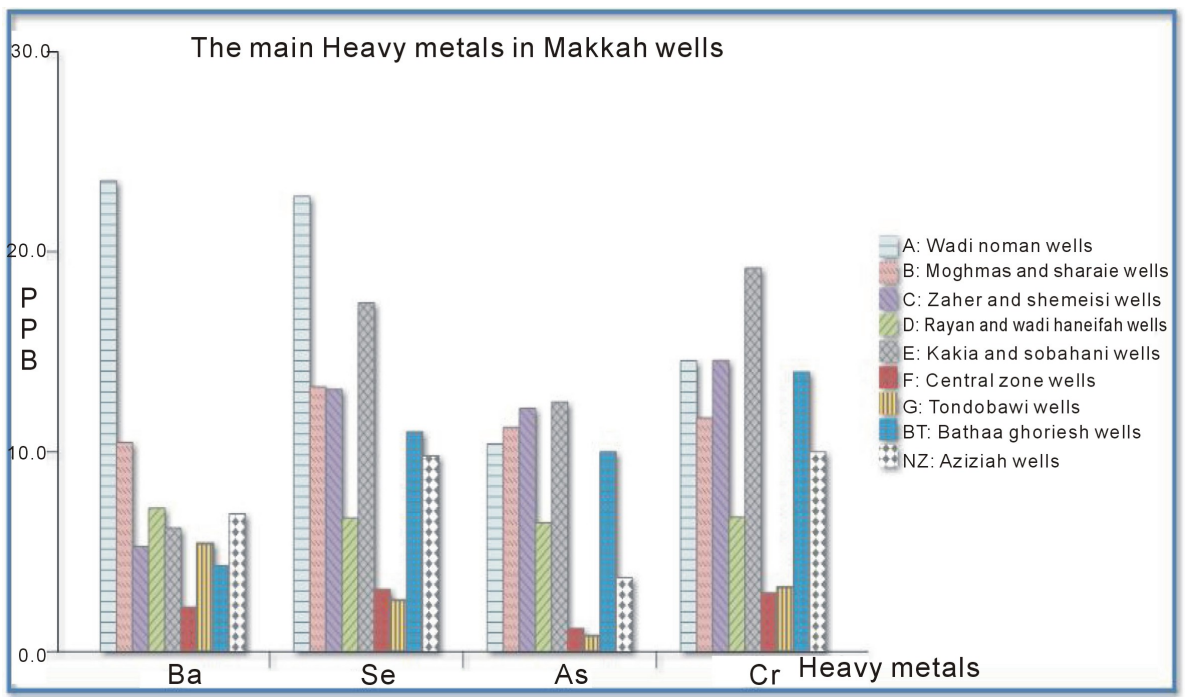

Figure 3. Four dominant heavy metals found in Makkah wells.

In this work, chromium was measured as total chromium, but it can be present in water in hexavalent (chromate) and trivalent forms. Water-soluble hexavalent chromium compounds are extremely irritating and toxic to human tissue. They were detected in levels below the international and local standards for drinking water as shown in Table 2. Daily intake is most important when considering human health. Chromate poisoning causes skin disorders and liver damage, and chromium is a dangerous contaminant in drinking water due to its suspected carcinogenic effects. Cadmium is released into the environment, especially groundwater, mainly from rocks in and around Makkah, cadmium has been found in shale, sandstone, limestone, metamorphic rocks, and stream sediment [6], and it could have infiltrated deep wells in Makkah from these sources. Cobalt, like other elements, is 
Table 2. Average heavy metal levels ( $\mu \mathrm{g} / \mathrm{L})$ in Makkah wells.

\begin{tabular}{ccccccccccc}
\hline Well Location & $\mathrm{Pb}$ & $\mathrm{Hg}$ & $\mathrm{Ba}$ & $\mathrm{Cd}$ & $\mathrm{Se}$ & $\mathrm{As}$ & $\mathrm{Cu}$ & $\mathrm{Co}$ & $\mathrm{Cr}$ \\
\hline $\mathrm{A}$ & 0.022 & 0.11 & 23.56 & 0.07 & 22.77 & 10.39 & 2.16 & 3.64 & 14.54 \\
$\mathrm{~B}$ & 0.0034 & 0.0052 & 10.46 & 0.0088 & 13.25 & 11.23 & 1.17 & 2 & 11.7 \\
$\mathrm{C}$ & 0.013 & 0.0013 & 5.26 & 0.042 & 13.13 & 12.17 & 2.86 & 1.35 & 14.56 \\
$\mathrm{D}$ & 0.044 & 0.039 & 7.17 & 0.02 & 6.68 & 6.45 & 0.77 & 1.28 & 6.73 \\
$\mathrm{E}$ & 0.006 & 0.015 & 6.18 & 0.027 & 17.44 & 12.49 & 3.87 & 1.87 & 19.2 \\
$\mathrm{~F}$ & 0.003 & 0.0038 & 2.24 & 0.037 & 3.12 & 1.14 & 0.87 & 0.57 & 2.93 \\
$\mathrm{G}$ & 0.0013 & 0.001 & 5.41 & 0.011 & 2.57 & 0.79 & 0.85 & 0.63 & 3.23 \\
$\mathrm{BT}$ & 0.0069 & 0 & 4.3 & 0.022 & 11 & 10 & 1.9 & 1.5 & 14 \\
NZ & 0 & 0.006 & 6.9 & 0 & 9.8 & 3.7 & 1.8 & 0.93 & 10 \\
Max & 0.022 & 0.11 & 23 & 0.07 & 22.77 & 12.49 & 3.87 & 3.64 & 19.2 \\
Min & 0.0034 & 0.00 & 4.3 & 0.0088 & 3.12 & 0.79 & 0.85 & 0.57 & 3.24 \\
SASO $^{*}$ & 10 & 1 & - & 5 & 50 & 10 & - & - & 50 \\
WHO $^{* * *}$ & 10 & 1 & 300 & 3 & 10 & 10 & 2000 & - & 50 \\
EPA $^{* * *}$ & 15 & 1 & 2000 & 5 & 50 & 50 & 1300 & - & 100 \\
EU $^{* * * *}$ & 10 & 1 & - & 5 & 10 & 10 & 2000 & - \\
\hline
\end{tabular}

*SASO standards ${ }^{* *}$ WHO standards, ${ }^{* * *}$ EPA standards ${ }^{* * * *}$ EU standards—no data available.

introduced into water through the dissolution of minerals and ores and erosion of local rocks. This study searched for even trace amounts of cobalt because of some reports correlating it to negative health effects. Cobalt is as a common arsenic sulfide mineral, along with cobalt, copper, and nickel. However, cobalt was found in very low concentrations, and no link between it and arsenic was seen in Makkah wells. Surprisingly, copper was found at very low concentrations and Lead is found in veins that are often connected to igneous rocks. Galena (lead sulfide, the only natural source for lead) is also found in limestone as either veins or replacement deposits. Lead appears in well water by forming soluble salts but was found in very low levels in Makkah well water. Very low concentrations of mercury were detected, which again could be because the rock type does not contain or produce soluble mercury salts. Methylation of trace inorganic mercury has been observed in fresh water and seawater, although almost all mercury in uncontaminated drinking water is thought to be the $\mathrm{Hg}^{2+}$ cation. Detecting minute traces of organic mercury such as methylmercury is difficult. The digestion process for mercury analysis was acidification followed by boiling to reduce the volume; however, no significant concentration of mercury was detected. The nine heavy metals studied were found in Makkah well water at extremely low concentrations, mostly within local and international standards. However, drinking water should not be polluted with even trace amounts of heavy metals, no matter what the source, natural or human. The average levels of all the nine metals detected are shown in Table 2, along with the SASO, WHO, EPA, and EU standards for drinking water.

All the maximum averages were within local and international standards for drinking water, except for arsenic and selenium. The average maximum arsenic level in the 168 wells exceeded the recommended SASO, WHO, and EU limits, while selenium exceeded WHO and EU standards. More details are shown in Table 3. Arsenic was detected in 72 wells (42\%) at levels greater than $10 \mu \mathrm{g} / \mathrm{L}$, exceeding SASO, WHO, and EU limits. Selenium was found in 102 wells (61\%) at levels exceed $10 \mathrm{ug} / \mathrm{L}$, exceeding WHO and EU limits. Barium levels were above $10 \mathrm{ug} / \mathrm{L}$ in 49 wells (29.5\%), within local and international limits. Chromium was found in 79 wells (47\%) at above $10 \mu \mathrm{g} / \mathrm{L}$, again within the established limits.

Further investigation was conducted by comparing the maximum levels detected in each individual well and the recommended standards. Table 4 shows that arsenic, mercury, and selenium stood out. Arsenic concentrations of $50 \mu \mathrm{g} / \mathrm{L}$ were found in two wells, selenium concentrations of $42 \mu \mathrm{g} / \mathrm{L}$ in two different wells, and a mercury concentration of $1.2 \mu \mathrm{g} / \mathrm{L}$ in one well. This is noteworthy for any future comparison, that the documented high levels were only in not more than two wells.

Wells with minimum $\mu \mathrm{g} / \mathrm{L}$ metal levels were found in different areas than those with maximum levels as shown in Table 5. Wells with the maximum levels were distributed inside and outside the city, but most of the wells with minimum levels were found inside the city, specifically the city center. One explanation for this distribution is that the lowest point in the city is the city center, and thus, the force of gravity drives rainwater and 
Table 3. Wells with heavy metals levels exceeding $10 \mu \mathrm{g} / \mathrm{L}$ from a total of 168 wells.

\begin{tabular}{cccc}
\hline Element & No. of wells & \% wells exceed $10 \mu \mathrm{g} / \mathrm{L}$ & Wells exceeding WHO standards \\
$\mathrm{Cr}$ & 79 & 47 & 0 \\
$\mathrm{Co}$ & 0 & 0 & 0 \\
$\mathrm{Cu}$ & 0 & 0 & 70 \\
$\mathrm{As}$ & 70 & 42 & 102 \\
$\mathrm{Se}$ & 102 & 61 & 0 \\
$\mathrm{Cd}$ & 0 & 0 & 0 \\
$\mathrm{Ba}$ & 49 & 29.5 & 1 \\
$\mathrm{Hg}$ & 0 & 0 & 0 \\
$\mathrm{~Pb}$ & 0 & 0 & \\
\hline
\end{tabular}

Table 4. Maximum levels of heavy metals detected in Makkah wells.

\begin{tabular}{|c|c|c|c|c|c|}
\hline Element & $\operatorname{Max} \mu g / L$ & No. of wells & \%No. of wells & Valley names and Well code & Relationship to standards \\
\hline $\mathrm{Cr}$ & 32 & 3 & 1.8 & $\begin{array}{l}\text { Zaher and Shemeisi, } \\
\text { (SM3, SM7, SM8) }\end{array}$ & Within standards \\
\hline Co & 5.7 & 1 & 1 & WadiNoman, (A2) & Not mentioned in standards \\
\hline $\mathrm{Cu}$ & 4.8 & 2 & 1.2 & $\begin{array}{l}\text { Kakia and Sabahani, } \\
\text { (S3, S4, S5, S6, S7) }\end{array}$ & Within standards \\
\hline As & 50 & 2 & 1.2 & $\begin{array}{l}\text { Zaher and Shemeisi, } \\
\text { (SM3, SM8) }\end{array}$ & $\begin{array}{l}\text { Exceeds SASO, WHO, } \\
\text { and EU standards }\end{array}$ \\
\hline Se & 42 & 2 & 1.2 & $\begin{array}{l}\text { WadiNoman, } \\
\text { (A1, A2) }\end{array}$ & $\begin{array}{l}\text { Exceeds WHO and } \\
\text { EU standards }\end{array}$ \\
\hline $\mathrm{Cd}$ & 0.31 & 3 & 1.8 & $\begin{array}{l}\text { Zaher and Shemeisi, } \\
\text { (SM5, SM9, L2) }\end{array}$ & Within standards \\
\hline $\mathrm{Ba}$ & 44 & 1 & 1 & WadiNoman, (A2) & Within standards \\
\hline $\mathrm{Hg}$ & 1.2 & 1 & 1 & WadiNoman, (A17) & Exceeds all standards \\
\hline $\mathrm{Pb}$ & 0.98 & 1 & 1 & Ryan, WadiAlkheif, (F2) & Within standards \\
\hline
\end{tabular}

Table 5. Minimum levels of heavy metals detected in Makkah wells.

\begin{tabular}{ccccc}
\hline Element & Min $\mu \mathrm{g} / \mathrm{L}$ & No. of wells & \%No. of wells & Location \\
$\mathrm{Cr}$ & 0.44 & 2 & 1.2 & Rayan, R10, R11 \\
$\mathrm{Co}$ & 0.0036 & 2 & 1.2 & Rayan, R8, R11 \\
$\mathrm{Cu}$ & 0.280 & 3 & 1.8 & Tondobawi, T6 R8, R10, R11 \\
$\mathrm{As}$ & 0.14 & 1 & 0.6 & 0.6 \\
$\mathrm{Se}$ & 0.350 & 1 & 21 & Rayan, R11 \\
$\mathrm{Cd}$ & 0.00 & 35 & 0.6 & In most wells \\
$\mathrm{Ba}$ & 0.08 & 1 & 42 & In most wells \\
$\mathrm{Hg}$ & 0.00 & 70 & 19 & In most wells \\
$\mathrm{Pb}$ & 0.00 & 31 & &
\end{tabular}

floods from higher areas (areas around Makkah city, including rural areas) to the city center. Rainfall and flood water accumulate over the years and are renewed by occasional heavy rains. Another explanation is that the city's storm-water drainage network may also play a role. Further investigation is needed to target the possibility of any influence of the storm-water drainage system and to prove that the wells in the Makkah city center are supplied by renewal sources.

The average levels of the four most abundant metals detected in Makkah wells (arsenic, barium, chromium, and selenium) are shown in Table 6, along with their maximum levels.

In an attempt to use a single illustrative tool, Table 7 was generated to act as a quick reference for the presence of metal patterns [54]. Degrees of 4 to 1 (highest to lowest concentration in ppb) were assigned to each 
metal. The degrees representing metals found in the wells of different Makkah locations are shown. Chromium was the most prevalent, followed by selenium, barium, and arsenic, respectively.

The relation between elevation and water well contamination with heavy metals was investigated. The concentrations of heavy metals with altitude are illustrated in Table 8. The numbers in general show that when the

Table 6. Averages of the four most abundant heavy metal levels in Makkah wells.

\begin{tabular}{ccccc}
\hline Location & Cr & As & Se & Ba \\
\hline A & 14.54 & 10.39 & 22.77 & 23.56 \\
B & 11.7 & 11.23 & 13.25 & 10.46 \\
C & 14.56 & 12.17 & 13.13 & 5.26 \\
D & 6.73 & 6.45 & 6.68 & 7.17 \\
E & 19.2 & 12.49 & 17.44 & 6.18 \\
F & 2.93 & 1.14 & 3.12 & 2.24 \\
G & 3.23 & 0.79 & 2.57 & 5.41 \\
BT & 14 & 10 & 11 & 4.3 \\
\hline
\end{tabular}

Table 7. Relative intensity of the four most abundant heavy metals in Makkah wells.

\begin{tabular}{ccccccc}
\hline Location & Determined Pattern & As & Ba & Cr & Se & Comment \\
\hline A & $\mathrm{Ba}<\mathrm{Se}<\mathrm{Cr}<\mathrm{As}$ & 1 & 4 & 2 & 3 & North of Makkah \\
$\mathrm{B}$ & $\mathrm{Se}>\mathrm{Cr}>\mathrm{As}>\mathrm{Ba}$ & 2 & 1 & 3 & 4 & East of Makkah \\
$\mathrm{C}$ & $\mathrm{Cr}>\mathrm{Se}>\mathrm{As}>\mathrm{Ba}$ & 2 & 1 & 4 & 3 & North, North-west of Makkah \\
$\mathrm{D}$ & $\mathrm{Ba}>\mathrm{Cr}>\mathrm{Se}>\mathrm{As}$ & 1 & 4 & 3 & 2 & North-East of Makkah \\
$\mathrm{E}$ & $\mathrm{Cr}>\mathrm{Se}>\mathrm{As}>\mathrm{Ba}$ & 2 & 1 & 4 & 3 & South of Makkah \\
$\mathrm{F}$ & $\mathrm{Se}>\mathrm{Cr}>\mathrm{Ba}>\mathrm{As}$ & 1 & 2 & 3 & 4 & City Center of Makkah \\
$\mathrm{G}$ & $\mathrm{Ba}>\mathrm{Cr}>\mathrm{Se}>\mathrm{As}$ & 1 & 4 & 3 & 2 & Center-West of Makkah \\
$\mathrm{BT}$ & $\mathrm{Cr}>\mathrm{Se}>\mathrm{As}>\mathrm{Ba}$ & 2 & 1 & 4 & 3 & West-South of Makkah \\
NZ & $\mathrm{Cr}>\mathrm{Se}>\mathrm{Ba}>\mathrm{As}$ & 1 & 2 & 4 & 3 & East of Makkah \\
(total 9 locations) & $\mathrm{Mean}$ prevalent rate : & 1.4 & 2.2 & 3.3 & 3 & \\
\hline
\end{tabular}

Table 8. Levels of heavy metals ( $\mu \mathrm{g} / \mathrm{L})$ in some Makkah wells at different altitudes (m).

\begin{tabular}{|c|c|c|c|c|c|c|c|c|c|}
\hline \multirow{2}{*}{ Altitude } & \multicolumn{9}{|c|}{ Concentration $(\mu \mathrm{g} / \mathrm{L})$} \\
\hline & $\mathrm{Cr}$ & Co & $\mathrm{Cu}$ & As & Se & Cd & $\mathrm{Ba}$ & $\mathrm{Hg}$ & $\mathrm{Pb}$ \\
\hline 105 & 16 & 2.1 & 2.6 & 18 & 14 & 0.018 & 19 & 0.015 & 0.0069 \\
\hline 109 & 17 & 1.95 & 3.95 & 18.5 & 15 & 0.0065 & 5 & 0.0003 & 0.0085 \\
\hline 113 & 19 & 1.75 & 2.65 & 10.7 & 18.5 & 0.25 & 18.5 & 0.003 & 0.0095 \\
\hline 129 & 10 & 0.5 & 1.9 & 1.9 & 10 & 0.22 & 1.5 & 0.006 & 0.0034 \\
\hline 143 & 30 & 1.4 & 4.8 & 23 & 27 & 0.033 & 5.6 & 0.00 & 0.0048 \\
\hline 153 & 7.3 & 0.68 & 1.4 & 1.9 & 6.8 & 0.0075 & 1.00 & 0.00 & 0.0048 \\
\hline 568 & 17 & 4.6 & 1.5 & 15 & 25 & 0.047 & 28 & 0.25 & 0.009 \\
\hline 787 & 6.8 & 1.6 & 0.76 & 3.1 & 9.7 & 0.000 & 10 & 0.013 & ND \\
\hline 760 & 9.6 & 2.1 & 0.9 & 5.8 & 14 & 0.00 & 14 & 0.014 & ND \\
\hline 671 & 5.2 & 2.6 & 0.7 & 1.6 & 6.9 & 0.034 & 11 & 0.017 & 0.0069 \\
\hline 649 & 3.9 & 1.8 & 0.96 & 1.8 & 5.2 & 0.000 & 15 & 0.018 & 0.012 \\
\hline 637 & 4.6 & 1.7 & 0.97 & 2.3 & 7.7 & 0.034 & 2 & 0.00 & 0.018 \\
\hline
\end{tabular}


altitude increase the concentration of heavy metal decrease (inverse proportion). However, this is not a case with all heavy metals and could be due two to reasons; the first one is man-made contamination such industrial waste and the other reason is that the contamination due to the composition of rock which has an impact on the water quality.

\section{Conclusion}

Makkah city is not an industrial center and, as such, does not have significant human-caused air or groundwater pollution. The presence of contaminants such as heavy metals in well water, therefore, must be due to the geological features surrounding Makkah. This work provides a building block for future research to supply documented scientific evidence to determine whether it is necessary to use suitable filters in agriculture and medically sensitive facilities, particularly dialysis machines and schools that rely on local wells to minimize possible complications due to predictable levels of heavy metals. The wells with the fewest contaminants were inside the city. No significant influences on the levels of contaminants in Makkah wells were observed from either altitude or seasonal changes. More research is needed to monitor groundwater in and around Makkah to detect any unexpected changes in chemical composition due to the city's storm water drainage network. Well water in Makkah city and surrounding areas contains natural traces of heavy metals, primarily arsenic, barium, chromium, and selenium, at mostly stable levels year round.

\section{Acknowledgements}

The authors appreciate King Abdulaziz City for Science and Technology (KACST) for support and funding Phase II of this study under project number 33-817. Also we appreciate Ministry of Health, Makkah Health Affairs for support and using facilities and equipment during phase I of this study.

\section{References}

[1] McMurry, J. and Fay, R. (2004) Hydrogen, Oxygen and Water. In: Hamann, K.P., Ed., McMurry Fay Chemistry, 4th Edition, Pearson Education, New Jersey, 575-599.

[2] Mendie, U. (2005) The Nature of Water. The Theory and Practice of Clean Water Production for Domestic and Industrial Use. Lacto-Medals Publishers, Lagos, 1-21.

[3] Al-Hasawi, Z. and Hussein, K. (2012) Groundwater investigation in Rabigh Governorate, West of Saudi Arabia. Global Advanced Research Journal of Environmental Science and Toxicology, 1, 72-79.

[4] Al-Ahmadi, M.E. (2005) Groundwater Quality in Some Villages Northeast of Jeddah City, Saudi Arabia. 9th International Water Technology Conference, IWTC9, Sharm El-Sheikh, 387-390.

[5] Al-Ibrahim, A.A. (1990) Water Use in Saudi Arabia: Problems and Policy Implications. Journal of Water Resources Planning and Management, 116, 375-388. http://dx.doi.org/10.1061/(ASCE)0733-9496(1990)116:3(375)

[6] Al-Solami, A., et al. (2009) Engineering Geological Mapping of the Holy City of Makkah Al Mukarramah, Saudi Arabia. Engineering Geology of Tomorrow's Cities. Geological Society, Engineering Geology Special Publication, London, 22.

[7] Robinson, J.R. (2010) Webster's Dictionary Definition of Creativity. Online Journal for Workforce Education and Development, 3, 2.

[8] Marcovecchio, J.E., Botté, S.E. and Freije, R.H. (2007) Heavy Metals, Major Metals, Trace Elements. Handbook of Water Analysis, 2, 275-311.

[9] Vodela, J., et al. (1997) Drinking Water Contaminants (Arsenic, Cadmium, Lead, Benzene, and Trichloroethylene). 2. Effects on Reproductive Performance, Egg Quality, and Embryo Toxicity in Broiler Breeders. Poultry Science, 76, 1493-1500. http://dx.doi.org/10.1093/ps/76.11.1493

[10] Iwashita, M. and Shimamura, T. (2003) Long-Term Variations in Dissolved Trace Elements in the Sagami River and Its Tributaries (Upstream Area), Japan. Science of the Total Environment, 312, 167-179. http://dx.doi.org/10.1016/S0048-9697(03)00251-1

[11] Wei, B. and Yang, L. (2010) A Review of Heavy Metal Contaminations in Urban Soils, Urban Road Dusts and Agricultural Soils from China. Microchemical Journal, 94, 99-107. http://dx.doi.org/10.1016/j.microc.2009.09.014

[12] Couzy, F., et al. (1992) Nutritional Implications of the Interactions between Minerals. Progress in Food \& Nutrition Science, 17, 65-87. 
[13] Tuormaa, T.E. (2000) Chromium, Selenium and Copper and Other Trace Minerals in Health and Reproduction. Journal of Orthomolecular Medicine, 15, 145-156.

[14] World Health Organization (2004) Guidelines for Drinking-Water Quality. Vol. 1. Recommendations. WHO.

[15] Schroeder, W., et al. (1972) World-Wide Occurrence of Nonallelic Genes for the y-Chain of Human Foetal Haemoglobin in Newborns. Nature, 240, 273-274.

[16] Stockinger, H. (1981) The Metals. In: Clayton, G.D. and Clayton, F.E., Eds., Patty’s Industrial Hygiene and Toxicology, Wiley, New York, 1493-2060.

[17] Elwood, P., St Leger, A. and Morton, M. (1977) Mortality and the Concentration of Elements in Tap Water in County Boroughs in England and Wales. British Journal of Preventive \& Social Medicine, 31, 178-182.

[18] Noonan, C.W., et al. (2002) Effects of Exposure to Low Levels of Environmental Cadmium on Renal Biomarkers. Environmental Health Perspectives, 110, 151-155. http://dx.doi.org/10.1289/ehp.02110151

[19] EPA (2011) Drinking Water Parameters. Safe Drinking Water Act (SDWA), EPA, USA.

[20] Goldhaber, S.B. (2003) Trace Element Risk Assessment: Essentiality vs. Toxicity. Regulatory Toxicology and Pharmacology, 38, 232-242. http://dx.doi.org/10.1016/S0273-2300(02)00020-X

[21] Tully, D.B., et al. (2000) Effects of Arsenic, Cadmium, Chromium, and Lead on Gene Expression Regulated by a Battery of 13 Different Promoters in Recombinant HepG2 Cells. Toxicology and Applied Pharmacology, 168, 79-90. http://dx.doi.org/10.1006/taap.2000.9014

[22] Papp, A., Feher, O. and Erdelyi, L. (1986) The Ionic Mechanism of the Pentylenetetrazol Convulsions. Acta Biologica Hungarica, 38, 349-361.

[23] Christie, N.T. and Tummolo, D.M. (1989) The Effect of Ni (II) on DNA Replication. Biological Trace Element Research, 21, 3-12. http://dx.doi.org/10.1007/BF02917231

[24] Xie, J., et al. (1995) Effects of Chelating Agents on Testicular Toxicity in Mice Caused by Acute Exposure to Nickel. Toxicology, 103, 147-155. http://dx.doi.org/10.1016/0300-483X(95)03134-2

[25] Iscan, M., Coban, T. and Eke, B.C. (1994) Differential Combined Effect of Cadmium and Nickel on Hepatic and Renal Glutathione S-Transferases of the Guinea Pig. Environmental Health Perspectives, 102, 69-72. http://dx.doi.org/10.1289/ehp.94102s969

[26] Nakamura, M., Yasukochi, Y. and Minakami, S. (1975) Effect of Cobalt on Heme Biosynthesis in Rat Liver and Spleen. Journal of Biochemistry, 78, 373-380.

[27] Eisler, R. (1998) Copper Hazards to Fish, Wildlife and Invertebrates: A Synoptic Review. DTIC Document, U.S. Department of the Interior, Geological Survey, Laurel.

[28] Kline, R., Hays, V. and Cromwell, G. (1971) Effects of Copper, Molybdenum and Sulfate on Performance, Hematology and Copper Stores of Pigs and Lambs. Journal of Animal Science, 33, 771-779.

[29] Bakare-Odunola, M. (2005) Determination of Some Metallic Impurities Present in Soft Drinks Marketed in Nigeria. The Nigerian Journal of Pharmaceutical Research, 4, 51-54.

[30] Hammer, M. and Hammer Jr., M. (2004) Water Quality. In: Water and Waste Water Technology, 5th Edition, Prentice-Hall, New Jersey, 139-159.

[31] Taueg, C., et al. (1992) Acute and Chronic Poisoning from Residential Exposures to Elemental Mercury-Michigan, 1989-1990. Clinical Toxicology, 30, 63-67. http://dx.doi.org/10.3109/15563659208994446

[32] Hussain, S., et al. (1999) Accumulation of Mercury and Its Effect on Antioxidant Enzymes in Brain, Liver and Kidneys of Mice. Journal of Environmental Science \& Health Part B, 34, 645-660. http://dx.doi.org/10.1080/03601239909373219

[33] Paul, D. and Dey, S. (2014) Selenium Content and Uptake in Crops as Affected by Soil Selenium Content and Implications on Human Health. Communications in Soil Science and Plant Analysis, 45, 429-436. http://dx.doi.org/10.1080/00103624.2013.872251

[34] Rosenfeld, I. and Beath, O.A. (1964) Selenium: Geobotany, Biochemistry, Toxicity and Nutrition. Economic Botany, 20, 340-343.

[35] Acar, K., Boz, B., Kurtuluş, A., Divrikli, U. and Elç, L. (2004) Using of Atomic Absorption Spectrometry for Diagnosis of Electrical Injuries (an Experimental Rat Study). Forensic Science International, 146S, S3-S4. http://dx.doi.org/10.1016/j.forsciint.2004.09.007

[36] Aremu, D.A., et al. (2002) Heavy Metal Analysis of Groundwater from Warri, Nigeria. International Journal of Environmental Health Research, 12, 261-267. http://dx.doi.org/10.1080/0960312021000001014

[37] Gan, W.-E., Shi, W.-W. and Su, Q.-D. (2004) Determination of Cadmium by CVAAS Using Nebulous Phase Reaction Vapor Generation System. Atomic Spectroscopy, 25, 245-250. 
[38] Koc, H., et al. (2004) Trace Metal Levels of Some Medical and Aromatic Plants Collected from High Density Traffic Areas in Tokat, Turkey. Asian Journal of Chemistry, 16, 1089-1092.

[39] Van Cauwenbergh, R., et al. (2004) Comparison of the Serum Selenium Content of Healthy Adults Living in the Antwerp Region (Belgium) with Recent Literature Data. Journal of Trace Elements in Medicine and Biology, 18, 99-112. http://dx.doi.org/10.1016/j.jtemb.2004.04.004

[40] Eaton, A.D., Clesceri, L.S. and Greenberg, A.E. (2005) Standard Methods for the Examination of Water and Wastewater. American Public Health Association, Washington DC, 20001-3710.

[41] Way, C. (2012) Standard Methods for the Examination of Water and Wastewater.

[42] Mizuike, A. (1983) Enrichment Techniques for Inorganic Trace Analysis. Springer-Verlag, Berlin. http://dx.doi.org/10.1007/978-3-642-68854-6

[43] Rao, T.P. and Biju, V.M.N. (2002) Ultratrace Analysis of Individual Rare Earth Elements in Natural Water Samples. Reviews in Analytical Chemistry, 21, 233-243. http://dx.doi.org/10.1515/REVAC.2002.21.3.233

[44] Zougagh, M., de Torres, A.G. and Pavón, J.M.C. (2002) Determination of Cadmium in Water by ICP-AES with On-Line Adsorption Preconcentration Using DPTH-Gel and TS-Gel Microcolumns. Talanta, 56, 753-761. http://dx.doi.org/10.1016/S0039-9140(01)00605-1

[45] Pereira, A., et al. (2010) Preconcentration and Determination of Cu(II) in a Fresh Water Sample Using Modified Silica Gel as a Solid-Phase Extraction Adsorbent. Journal of Hazardous Materials, 175, 399-403. http://dx.doi.org/10.1016/j.jhazmat.2009.10.018

[46] Khdary, N.H. and Howard, A.G. (2011) New Solid-Phase-Nanoscavenger for the Analytical Enrichment of Mercury from Water. Analyst, 136, 3004-3009. http://dx.doi.org/10.1039/c1an15075h

[47] Yamini, Y., Hosseini, M.H. and Morsali, A. (2004) Solid Phase Extraction and Flame Atomic Absorption Spectrometric Determination of Trace Amounts of Zinc and Cobalt Ions in Water Samples. Microchimica Acta, 146, 67-72. http://dx.doi.org/10.1007/s00604-003-0171-5

[48] Tuzen, M., Saygi, K.O. and Soylak, M. (2008) Solid Phase Extraction of Heavy Metal Ions in Environmental Samples on Multiwalled Carbon Nanotubes. Journal of Hazardous Materials, 152, 632-639. http://dx.doi.org/10.1016/j.jhazmat.2007.07.026

[49] Citak, D. and Tuzen, M. (2010) A Novel Preconcentration Procedure Using Cloud Point Extraction for Determination of Lead, Cobalt and Copper in Water and Food Samples Using Flame Atomic Absorption Spectrometry. Food and Chemical Toxicology, 48, 1399-1404. http://dx.doi.org/10.1016/j.fct.2010.03.008

[50] Bakircio, Y., Bakircioglu, D. and Akman, S. (2004) Use of a Packed Mini-Column Connected to a Syringe for Determination of Trace Elements in Biological and Water Samples by Flame Atomic Absorption Spectrometry. Microchimica Acta, 148, 191-197.

[51] Praveen, R., Daniel, S. and Rao, T.P. (2005) Solid Phase Extraction Preconcentration of Cobalt and Nickel with 5,7-Dichloroquinone-8-Ol Embedded Styrene-Ethylene Glycol Dimethacrylate Polymer Particles and Determination by Flame Atomic Absorption Spectrometry (FAAS). Talanta, 66, 513-520. http://dx.doi.org/10.1016/j.talanta.2004.11.026

[52] Khdary, N.H. and Turkistani, A.H.M. (2009) Using Total Dissolved Substances (TDS) to Recognize the Sources of Drinking Water in Central Area of Makkah Al-Mukaramah. Journal of Saudi Chemical Society, 409, 29-36.

[53] Brenniman, G. and Levy, P. (1984) Epidemiological Study of Barium in Illinois Drinking Water Supplies. In: Clabrese E.J., Ed., Advances in Modern Toxicology, Princeton Scientific Publications, Princeton, 231-240.

[54] Gassim, A. (2005) Relative Level of Heavy Metals in Drinking Water. Guidelines Report 1426, Toxicology Center of Makkah Region, Makkah, 2-6. 
Scientific Research Publishing (SCIRP) is one of the largest Open Access journal publishers. It is currently publishing more than 200 open access, online, peer-reviewed journals covering a wide range of academic disciplines. SCIRP serves the worldwide academic communities and contributes to the progress and application of science with its publication.

Other selected journals from SCIRP are listed as below. Submit your manuscript to us via either submit@scirp.org or Online Submission Portal.
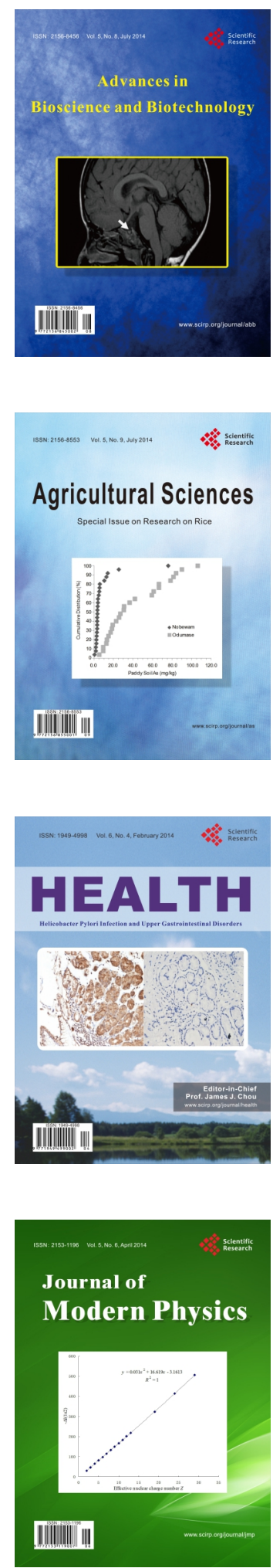
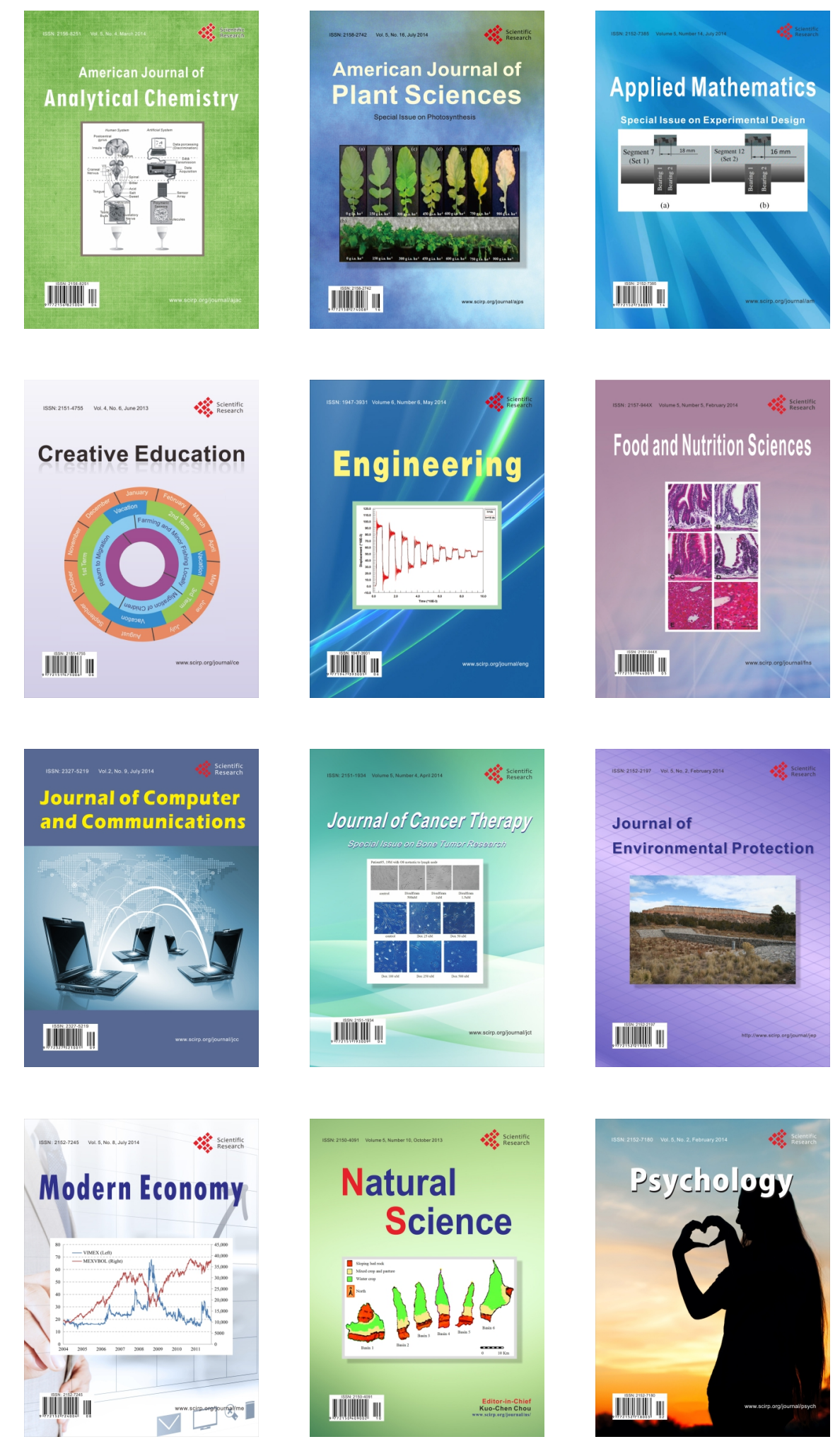